\title{
SPECIALIZATION OF EUROPEAN WORKERS IN TIMES OF ECONOMIC RECESSION AND EXPANSION
}

\author{
Tatiana Polonyankina $a^{a^{*}}$ \\ a Lecturer,University of Economics, Prague, Department of Econometrics, Czech Republic Tatiana.polonyankina@vse.cz \\ *Corresponding author.
}

Received: 2 October 2018, accepted: 6 November 2018, published: 31 January 2019

\begin{abstract}
Majority of studies proved that labour mobility and effects of immigration differ with respect to the business cycle. The aim of the paper is to summarize differences in occupation allocation of native workers after immigration increase within European countries during recession and expansion period. The presented analysis split European counties on two groups: a) West and South Europe; b) Middle and East Europe (post-communist economies). The specialization of workers is investigated concentrating on differences between natives and immigrants with secondary or lower education between years 2000 and 2011. A sizable relocation of native workers to occupations with more interactive rather than manual content after an increase of immigration was found in West and South European counties for the expansion period. This effect was not found for the recession period and for the post-communist economies.
\end{abstract}

Keywords: business cycle, task specialization, European Union, labour markets, immigration

\section{INTRODUCTION}

Literature, that analyses workers specialization with respect to their origin, has the theoretical background in a neoclassical economic model firstly used by Peri and Sparber (2009). The theoretical model assumes a final tradable consumption good produced using two non-tradable intermediate services: supply of highly-educated workers (university education and professionals) and supply of less-educated workers (secondary and lower education). The less-educated workers are assumed to be split on two groups: native and immigrant workers, which may differ from one another in relative task productivity. The native workers are assumed to be more productive in communicational rather than manual tasks in opposite to immigrants. The immigrants are assumed to be more productive in manual rather than productive tasks. All workers are assumed to use their comparative advantage on labour market.

Peri and Sparber (2009) and Amuedo and De la Rica (2011) investigated labour markets of the United States and Spain during their expansion periods applying the neoclassical economic model. The findings of both papers show that lesseducated native workers adjust to an increase in less-educated immigrant workers in the country by changing their task specialization. In particular, less-educated natives appear to shift to occupations with a lower manual, a higher interactive, task content. The both studies analysed the labour markets in times of economic expansion.

Peri (2010) studied the impact of immigrants on the US economy during recession and economic expansion. He found that the short-run effect of immigrants depends on the state of the economy. In an expansionary period, immigration creates jobs and natives are not displaced from the labour market. However, during a recession, the economy does not absorb immigration so quickly and there seems to be a small negative impact on native unemployment in the short run (but not in the long run). Giving that, there is a change in the way in which the labour market reacts to immigration https://doi.org/10.30585/icabml-cp.v2i1.219

(c) 2018 the Authors. Production and hosting by Avicenna FZ LLC. on behalf of Dubai Business School, University of Dubai - United Arab Emirates. This is an open access article under the CC BY-NC license. 
with respect to the state of the economy. The findings about native relocation after immigration increase of Peri and Sparber (2009) and Amuedo and De la Rica (2011) can be no longer valid in times of economic recession.

Differences of natives' specialization with respect to the business cycle was found for Spain by De la Rica and Polonyankina (2013), also using the neoclassical economic model. The relocation pattern was found for the expansion period, similarly to Amuedo and De la Rica (2011). The authors conclude that there is no evidence of any relocation of natives to different occupations as a response to an immigration shock in the recession period in Spanish labour markets. Second, in the recession no impact of immigration on the employment levels of natives was found, but the authors do find a sizable negative impact on the employment levels of earlier immigrants.

The paper is based on the research of Polonyankina (2016), where the analysis of workers relocation is expanded on 13 countries of European Union in different stages of business cycle. The research gives comparison of native workers relocation effect after increased immigration in recession and expansion period for two groups of European countries:

a) West and South Europe;

b) Middle and East Europe (post-communist economies).

The chapter theoretical model introduces the neoclassical model of Peri and Sparber (2009). Data are described in the next chapter putting attention on creation of task measurement of occupations. The chapter methodology describes estimation models and used methods applying instrumental variable and weighted least square estimation. Results are summarized in the chapter Findings. The paper is finished with conclusions.

\section{THEORETICAL MODEL}

The theoretical background for majority of the studies in the introduction is given by the neoclassical economic model of Peri and Sparber (2009). The theoretical model is explaining the native occupation relocation after increase of immigration. The model assumes a final tradable consumption good produced using two non-tradable intermediate services: the supply of highly-educated workers (university education and professionals) and the supply of lesseducated workers (secondary and lower education).

Next, only the supply of less-educated workers is explained, assuming supply of highly-educated workers being constant. The supply of less-educated workers can be split on two groups: native and immigrants. The model assumes that these workers specialize using their comparative advantage in task performance where:

a) natives have comparative advantage in non-manual skills,

b) immigrants have comparative advantage in manual skills.

Natives are assumed to be better at interactive tasks than in manual tasks, since they are native speakers of the country they work in and have the knowledge of local culture. Immigrants are assumed to be better at manual tasks than in interactive tasks, since they are more likely to struggle with the country language and have lack of host country specific human capital.

The main idea of the model: Immigration increase the supply of manual tasks in the country, since immigrants using their comparative advantage concentrate in positions with more manual content. The increase of supply of manual tasks on labour market leads to reduction of the compensation to manual skills and increase in the compensation to non-manual position. Natives respond rationally and using their comparative advantage relocate to non-manual positions.

The validity of the model is tested in this paper where the average ratio of manual to interactive skills used in current job of natives is tested for dependence on share of immigrants in regions of European union controlling for other individual characteristics (fore more see the chapter methodology),

\section{DATA}

The presented analysis works with individual data adjusted for the assumptions of the theoretical model. Only economically active population with secondary and lower education is considered. Competition between natives and immigrants is more likely to occur in low-skill positions when majority of immigrants in analysed time period is without university education. As foreigner is considered an individual who were born outside of the survey country and were not citizens at birth. A subset of this immigrants is used, including only foreigners who stay in a country less than 5 years. Since, it is assumed that recent immigrants have spent less time in the European Union so they are less likely to 
already have specific human capital skills and the language proficiency and more likely to have the assumed comparative advantage.

The Eurostat Labour Force Survey (LFS) is used as source data where individuals were merged on NUTS 2 regions granularity. The ISCO occupations on level 3 are available about each individual. For expansion, the Western Europe is studied in years 2000-2007 including countries: Finland, France, Greece, the Netherlands, Portugal, Spain, Great Britain, Belgium. For recession, the Western Europe is studied in years 2008-2011 and countries: Austria, Denmark, Finland, France, Greece, Ireland, Italy, Norway, Netherlands, Portugal, Spain, Great Britain, Belgium. The Central and Eastern Europe is studied in 2004-2011 and includes: Slovakia, Czech Republic, Hungary. In 2007-2011 Romania. In the period 2008-2011 Bulgaria.

The limitation of the LFS dataset should be mentioned. Firstly, the data about post-communist countries were available only after their accession to the European Union. Secondly, the surveys generally tend to under-sample immigrants. The LFS may not capture migrants without the legal right to work in the host country. Tepperova and Zouhar (2016) also highlight 2 more aspects: Firstly, in most EU15 countries, the survey excludes collective households, such as halls of residence that contain many immigrants and workers in general, or hotels where new arrivals might reside. Secondly, as participation in the survey is voluntary in many countries, it is possible that migrants exhibit a higher refusal rate (due to, e.g. language barriers, since LFS data are often collected via phone calls).

Task specialization of native workers is measured as relative manual to interactive tasks ratio used in a current occupation of a worker. Manual and non-manual tasks measure is based on the task requirements for each occupational classification provided by the U.S. Department of Labour through its $\mathrm{O}^{*}$ Net occupation classification which is merged with the International Standard Classification of Occupations. The manual-to-interactive relative task ratio for each occupation is created as the weighted average manual task content divided by the average interactive task content (for more see Polonyankina (2016) and De La Rica, S., Polonyankina, T. (2013)). The figure below present manual and communicational tasks used across 8 ISCO occupations ${ }^{1}$.

Average tasks required

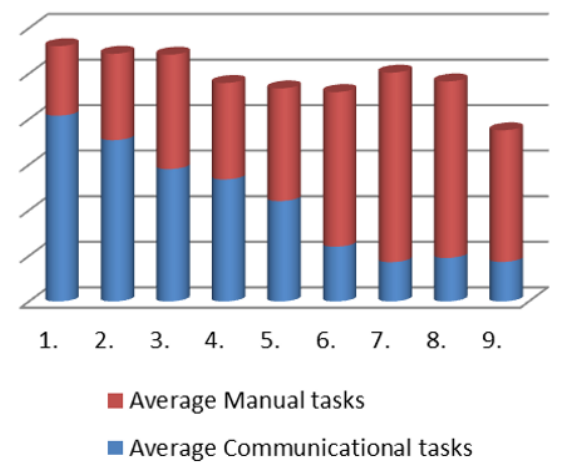

\section{Relative manual to interactive} tasks Ratio

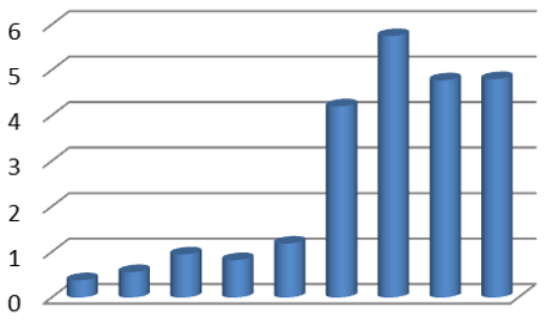

1. 2. 3. 4. 5. 6. 7. 8.9 .

- relative manual to interactive tasks Ratio

Figure 1. Manual and Communicational Tasks in ISCO Occupations ${ }^{1}$

Reference: Polonyankina (2016)

\section{METHODOLOGY}

In order to test the validity of the theoretical model, firstly merged native workers with manual-to-interactive tasks scoring of their current occupation based on $\mathrm{O}^{*}$ Net Survey. Next, individual data were merged by region creating panel data. The final analysis estimated dependence of the average manual-to-interactive task ratio of native workers in a region in particular year on share of immigrants in the region in particular year and other explanatory demographic variables.

\footnotetext{
${ }^{1}$ Occupations were created by ISCO with levels: 1 . managers, 2 . professionals, 3. technicians and associated professionals, 4. clerical support workers, 5. service and sales workers, 6. skilled agricultural, forestry and fishery workers, 7. craft and related workers, 8. plant and machine operators, and assemblers, 9. elementary occupations.
} 
The estimated equation (1) below is used by Polonyankina (2016) and was derived from the theoretical model of Peri and Sparber (2009) described in the second chapter.

$$
\ln \left(\frac{M}{C}\right)_{\text {native, } c t}=\theta+\delta \ln f_{c t}+\lambda_{1} e d u c_{c t}+\lambda_{2} a g e 2_{c t}+\lambda_{3} a g e 3_{c t}+\lambda_{4} a g e 4_{c t}+\lambda_{5} a g e 5_{c t}+\varepsilon_{c t},
$$

where $t$ is time index and $c$ is region index; $\ln \left(\frac{M}{C}\right)_{\text {native, } c t}$ is the average manual-to-interactive task ratio of natives in each cell; $f_{c t}$ represents the share of foreign-born workers in each cell, $e d u c_{c t}$ the average education in the cell; age $2_{c t}$ to age $5_{c t}$ age groups in each cell; $\varepsilon_{c t}$ is error term.

Polonyankina (2016) also uses the second method how to test importance of business cycle is to use the unit root test. The method is using one merged data set that consist of both recession and expansion periods. A dummy variable crisis $_{t}$ with value 1 for recession and 0 for expansion is introduced. The obtained second equation for estimation is:

$$
\begin{gathered}
\ln \left(\frac{M}{C}\right)_{\text {native, } c t}=\theta+\delta \ln f_{c t}+\lambda_{1} e d u c_{c t}+\lambda_{2} a g e 2_{c t}+\lambda_{3} a g e 3_{c t}+\lambda_{4} a g e 4_{c t}+\lambda_{5} a g e 5_{c t}+\rho c r i s i s_{t} * \\
\ln f_{c t}+\varepsilon_{c t},(2)
\end{gathered}
$$

The Weighted Least Square (WLS) estimation is used in which the weights are the number of individuals in each cell. Robust standard errors clustered by province are reported under the estimates. The panel is also tested for unobserved heterogeneity using Hausmann test concluding use of fixed effects. Immigrants do not settle randomly across regions, given that the endogeneity of the share of foreign-born workers must be accounted for. We use instrumental variables (IV) assuming that the main determinant for the decision of recent immigrants on where to locate is the settlement of previous immigrants (based on the literature).

For both equations the parameter of interest is $\delta$. The theoretical model assumes relocation of natives on occupations more interactive tasks assuming a negative value of $\delta$. The significant estimation of the parameter means that after immigration increase that evidence of possible relocation of natives after immigration increase was found.

\section{FINDINGS}

The findings of the analysis are summarized at the table 1 where impacts of a change in recent immigrant share on native workers average manual to interactive skills ratio was estimated using the equation (1) applying IV and WLS and using the equation (2) applying WLS.

Table 1. Main Results: Changes in relocation of native workers

\begin{tabular}{cc}
\hline West and South Europe & Relocation of native workers \\
\hline Expansion period IV and WLS (2000-2007) & Yes \\
Recession period IV and WLS (2008-2011) & No \\
Unit root test WLS (2000-2011) & Yes \\
\hline Middle and East Europe & Relocation of native workers \\
\hline No split WLS (2004-2011) & No
\end{tabular}

The evidence of native relocation was found for the expansion period. Natives move to occupations with more interactive (rather than manual) skills as immigration increases during the expansion period in West and South Countries of European Union. The same results were also obtained by Polonyankina and De la Rica (2013) for Spain and Peri and Sperber for US (2009). Men have the higher ratio of manual to interactive skills than women. The highest ratio of manual to interactive skills have citizens up to 30 years and the lowest citizens older than 60 years. Citizens with secondary education on average work in positions with lower ratio of manual to interactive skills than citizens with basic and lower education.

During the recession, the effect of specialization of citizens with a higher migration was not found. Number of migrant workers in the Western European countries declined with the coming of the crisis. The effect can be connected with increasing uncertainty and lack of jobs during recession makes labour market mobility more difficult. The effect of relocation was found to be dependent on business cycle also applying the unit root test.

The Easter and Middle European countries belong to the post-communist countries with lower GDP and price level than the rest of EU. The effect of native relocation was not found. The results could be affected by several facts: the number 
of foreigners is significantly lower than in Western European countries, for these countries is typical outflow of workforce into more stable Western economies, they access European Union later.

\section{CONCLUSIONS}

The analysis investigated relocation of workers with secondary and lower education during different stages of business cycle for two groups of European countries. The native specialization shift depends on the business cycle for West and South Europe. The native workers respond to immigration by relocating to occupations with more interactive, rather than manual, content in expansion period. No displacement effect of task specialization of natives for recession period was found. Natives may find difficult to move to other occupation, given that there is lack of jobs and overall uncertainty on labour markets in times of economic recession.

The effect of a change of specialization of natives was not found for the analysed post-communist countries. The results could be affected by the several facts: a) There is lower number of immigrants then is West and South countries. There is high number of workers who migrate to work in other European counties. B) The analysis was done recently after the enlargement of the European Union when these economies could be in process of adjustment to open European labour markets.

The further steps of the research can try to explain the adjustment of labour markets on immigration in recession. It might be the case that recent immigrants compete more with immigrants who are longer at the country in recession in European union, the results of Polonyankina and De la Rica (2013) for Spain suggest that.

\section{REFERENCES}

Amuedo-Dorantes, C. \& De la Rica, S. (2011). Complements or Substitutes? Task Specialization by Gender and Nativity in Spain, Labour Economics, 18, 697-707. http://www.sciencedirect.com/science/article/pii/S0927537111000297

Angrist, J., D. \& Kruger A., B. (2001). Instrumental Variables and the Search for Identification: From Supply and Demand to Natural Experiments, Journal of Economic Perspectives, 15(4). DOI: 10.1257/jep.15.4.69

De La Rica, S. \& Polonyankina, T. (2013). The Impact of Immigration on Occupational Specialisation among Natives in Spain: Does the Business Cycle Matter? Revista de Economia Aplicada, 21(63), 51-75. http://www.redalyc.org/articulo.oa?id=96929566003

Peri, G. \& Sparber, C. (2009). Task specialization, Immigration and Wages. American Economic Journal: Applied Economics, 1(3), 135169.

http://dx.doi.org/10.1257/app.1.3.135

Peri, G. (2010). The Impact of Immigrants in Recession and Economic Expansions, Washington, DC, Migration Policy Institute.

Polonyankina, T. (2016). The Impact of Immigration on Occupational Specialization of European Union Citizens, Politicka ekonomie, 2: 193-208.

https://doi.org/10.18267/j.polek.1063

Tepperová, J., Zouhar, J., Wilksch, F. (2016). Intra-EU migration: legal and economic view on jobseekers' welfare rights. Journal of International Migration and Integration, 17: 1-20.

https://link.springer.com/article/10.1007/s12134-016-0509-6

Wooldridge, J. M. (2002). Econometric Analysis Of Cross Section and Panel Data. MA: MIT Press. ISBN: 9780262232586.

\section{ACKNOWLEDGMENTS}

The work on this paper was supported by IGS F4/60/2018, University of Economics, Prague. 